\title{
Effect of Light Intensity during the Growing Period on Ascorbic Acid Content and Its Histochemical Distribution in the Leaves and Peel, and Fruit Quality of Satsuma Mandarin
}

\author{
Hidemi Izumi, Takuji Ito and Yasuji Yoshida \\ Experimental Farm, Kinki University, Yuasa, Wakayama 643
}

\begin{abstract}
Summary
Three-year-old satsuma mandarin (Citrus unshiu Marc. cv. Miyamoto Wase) trees were grown under 4 different light conditions (100, 50,20 and 5\% levels of full sunlight) from July to October.

Ascorbic acid (AsA) and sucrose contents in the leaves of spring shoots in October were reduced by lowering light intensity; chlorophyll content was higher in shaded leaves than in those of the control (100\% of full sunlight). A microscopic observation revealed that distribution of AsA was prevalent in the parenchymatous cells of palisade and spongy tissues of leaves. Density of AsA in mesophyll tissues showed a tendency to be low with lower light intensity.

The mature fruits harvested from trees grown at $20 \%$ full sunlight were inferior in fruit size and peel color (a/b value); they contained lower AsA and sugar contents in the juice and flavedo as compared to the values found in nonshaded control fruits. These components were even lower in fruits from the $5 \%$ full sunlight treatment. On the other hand, titratable acid content increased with decreasing light intensity.

A microscopic observation of the peel cross-sections revealed that AsA was ubiquitous in the flavedo tissues of fruits that had received enough sunlight, whereas there was little AsA in flavedo tissues in the adjacent albedo of the fruits from shaded trees (20 and $5 \%$ levels of full sunlight).

From these results, we conclude that light intensity during fruit growth affects the concentration and distribution of AsA in satsuma mandarin leaves and fruits, and that shading below $20 \%$ full sunlight results in significantly low AsA content and poor fruit quality.
\end{abstract}

\section{Introduction}

It is well known that citrus fruit quality is affected by such environmental factors as light, temperature, water supply, nutrition, and soil characteristics during the growing period (Sinclair, 1984). Numerous reports indicate the effect of different light intensities on the fruit quality of satsuma mandarin in Japan (Ashizawa et al., 1969; Kuriyama and Shiraishi, 1970; Nii and Deguchi, 1972; Ono and Iwagaki, 1987). These studies are mainly concerned with fruit size, rind color, soluble solids, and sugar and acid contents in juice. However, very little has been reported on ascorbic

Received for publication 19 August 1991. Studies on vitamin $\mathrm{C}$ of fruits and vegetables. Part VIII. acid (AsA) content in fruit in relation to light intensity (Suzuki et al., 1988). Little is known about the relationship between light intensity and AsA content and AsA distribution in satsuma mandarin fruits.

We have reported the effect of different light intensities in various areas of the tree canopy on the amount of AsA in the leaves (Izumi et al., 1990b) and fruits (Izumi et al., 1988, 1990a) of satsuma mandarin. These data showed that leaves and fruits from the sunlit exterior canopy received more sunlight during development than those from the shaded interior canopy, had a higher AsA content.

The purpose of this study was to elucidate the effect of light intensity on AsA content in the leaves and fruits, on the distribution pattern of 
AsA in leaf and rind tissues, and on fruit quality, by using young satsuma mandarin trees grown in four different light conditions. Because fruits of high quality are desirable, this investigation was undertaken with more precision than that taken previously to study the relationship between AsA and fruit quality as dependent variables and light intensity as the independent variable.

\section{Materials and Methods}

\section{Plant materials and growing conditions}

Three-year-old potted trees of satsuma mandarin (Citrus unshiu Marc. cv. Miyamoto Wase) grown outdoors were used for this study in 1989. Thirtytwo trees bearing about 15 fruits each were selected. Eight trees were kept in full sunlight as control and 24 trees were treated with shading by covering with two types of black shading cloths from 19 July to 19 October. One-third of the treated trees was grown under a layer of black cheesecloth 600 \# (50\% level of full sunlight), onethird under a layer of black synthetic fiber cloth used for ordinary shading or cold protection of plants ( $20 \%$ level of full sunlight), and another onethird under two layers of the same shading cloth (5\% level of full sunlight). These shading cloths were kept horizontal at $50 \mathrm{~cm}$ height above the ground in order to assure good ventilation and to facilitate watering. Customary watering and chemical spray were routinely carried out on all test trees. Daytime temperature under the shaded condition was found to be $2^{\circ}$ to $4^{\circ} \mathrm{C}$ higher than the ambient temperature.

\section{Leaf and fruit analysis}

In late October, about 3 months after the onset of the treatment, thirty leaves from spring shoots were sampled from each treatment. The determination of the components was conducted by using mesophyll parts. The determination of AsA, chlorophyll and sugar contents was replicated 3 times according to the methods described previously (Izumi et al., 1990b).

Twenty-eight mature fruits from each treatment were harvested in late October. Fruit size, peel color (a/b value; Tokyo Denshoku, Model TC-P2), AsA and sugar contents in flavedo, and AsA, sugar, and titratable acid contents in juice were determined by the methods described in previously
(Izumi et al., 1988, 1990a). The analyses were replicated 4 times.

\section{Histochemical determination of AsA}

Histochemical determination of AsA was performed by a modified method of Sosa (1952) and Kurosaki and Kawakami (1974). This method is based on the reducing ability of AsA in an acidic medium. Tissue slices $(2 \times 2 \mathrm{~mm})$ were removed from the central area of the laminae of leaves and from the flavedo portion of peel along the equator with a razor blade in late October. The leaf and flavedo tissues were immersed for one hour in $100 \mathrm{ml}$ of $10 \%$ aqueous silver nitrate solution containing $1 \mathrm{ml}$ glacial acetic acid. This was followed by immersion in about 20 times of volume (in relation to the whole volume of the tissues) of $10 \%$ sodium sulphite for one hour. The tissues were transferred to 10 volumes of $10 \%$ sodium thiosulphate for one hour. All manipulations were carried out under dim light at room temperature. The tissues were finally fixed with FAA solution, embedded in paraffin resin, thin-sectioned $(7 \mu \mathrm{m})$, and stained with safranine and fast green for microscopic observation. The black deposits of metallic silver are the sites of AsA localization.

\section{Results}

\section{The influence of light intensity on the amount of AsA in the leaves}

1) Content of leaf components: AsA, chlorophyll and sugar contents in the leaves of young trees growing in full sunlight and under shading treatments are listed in Table 1. The leaves exposed to full sunlight attained the highest level of AsA among all tested conditions. They had four times more AsA as compared with leaves grown under 5\% full sunlight. Whereas AsA content was reduced by lowering light intensity, chlorophyll content increased with shading; leaves grown in $20 \%$ full sunlight contained the highest chlorophyll content. The predominant sugars in the leaves were glucose, fructose and sucrose. Sucrose content in shaded leaves decreased proportionately with decreasing light intensity. Fully exposed control leaves contained more glucose and fructose than did leaves shaded to $5 \%$ full sunlight, but they did not significantly differ from those under $50 \%$ and $20 \%$ full sunlight. 
Table 1. Effect of light intensity on ascorbic acid, chlorophyll and sugar contents in satsuma mandarin leaves ${ }^{2}$

\begin{tabular}{|c|c|c|c|c|c|}
\hline $\begin{array}{l}\% \text { full } \\
\text { sunlight }\end{array}$ & $\begin{array}{c}\text { Ascorbic acid } \\
(\mathrm{mg} / 100 \mathrm{~g} \mathrm{FW})\end{array}$ & $\begin{array}{l}\text { Chlorophyll } \\
\text { (mg/g FW) }\end{array}$ & $\begin{array}{c}\text { Glucose } \\
\text { (mg/g FW) }\end{array}$ & $\begin{array}{c}\text { Fructose } \\
\text { (mg/g FW) }\end{array}$ & $\begin{array}{c}\text { Sucrose } \\
(\mathrm{mg} / \mathrm{g} \mathrm{FW})\end{array}$ \\
\hline 100 & $180 a^{x}$ & $2.17 \mathrm{c}$ & $2.96 \mathrm{a}$ & $2.37 \mathrm{a}$ & $5.28 \mathrm{a}$ \\
\hline 50 & $150 \mathrm{~b}$ & $2.63 \mathrm{~b}$ & $2.65 \mathrm{a}$ & $2.21 \mathrm{a}$ & $4.32 \mathrm{~b}$ \\
\hline 20 & $94 \mathrm{c}$ & $3.03 \mathrm{a}$ & $2.62 \mathrm{a}$ & $2.27 \mathrm{a}$ & $3.67 \mathrm{c}$ \\
\hline 5 & $47 \mathrm{~d}$ & $2.73 \mathrm{~b}$ & $1.58 \mathrm{~b}$ & $1.27 \mathrm{~b}$ & $2.68 \mathrm{~d}$ \\
\hline
\end{tabular}

2) Histochemical distribution of AsA in leaf tissues: Histological distribution of ASA in the leaves of test plants was made visible by reducing silver from a silver nitrate solution. Fig. $1 \mathrm{~A}$ shows the dense black deposit of reduced silver granules in the heavily stained parenchymatous cells of the palisade and spongy tissues of the nonshaded control leaves, indicating a high concentration of AsA. Leaves shaded to $50 \%$ full sunlight exhibited a light deposit of silver granules in the mesophyll cells (Fig. 1B); leaves under $20 \%$ and $5 \%$ full sunlight showed even lower density of silver granules (Figs. 1C and 1D).

Palisade cells formed two distinct layers in the leaves exposed to full sunlight, $50 \%$, and $20 \%$ full sunlight, whereas only one layer of smaller palisade cells formed in the heavily shaded leaves (Fig. 1D). Small cells and a thin palisade tissue are typical manifestation of shaded citrus leaves.

\section{The influence of light intensity on the fruit qual-} ity and $A s A$ content

1) Fruit quality: Quality of fruit harvested from trees grown in 4 different light conditions was determined in late October.

Fruits grown in 50\% full sunlight were smaller in transverse diameter and lighter in weight, whereas those grown at $20 \%$ and $5 \%$ full sunlight were significantly smaller in size and weight, and their peel color ( $\mathrm{a} / \mathrm{b}$ value) was poorer than that of fruits from the control trees (Table 2).

Sugars in the flavedo and juice consisted of glucose, fructose and sucrose. Compared with fruits from the nonshaded control trees, AsA and fructose contents were found to be lower in the flavedo of fruits from trees grown under $20 \%$ and $5 \%$ full sunlight treatments, whereas glucose content was lower in the $50 \%, 20 \%$ and $5 \%$-full sunlight treatments; sucrose content was lower in only 5\%-full sunlight (Table 3). Lower contents of AsA, glucose, fructose and sucrose in the juice were observed in the fruits from $20 \%$ full sunlight treatment in contrast to the nonshaded control. These components were in even lower concentration in the fruits grown under the $5 \%$ full sunlight than in the fruits from the $20 \%$ full sunlight treatment. On the contrary, titratable acid content (as citric acid) tended to increase with decreasing light intensity (Table 4).

The above results indicate that shading to $20 \%$ full sunlight or less during the growing period significantly affected size, peel color, and AsA and sugar contents in satsuma mandarin fruits.

2) Histochemical distribution of $A s A$ in flavedo tissues: A photomicrograph of the flavedo tissues from fruits taken from the full sunlight plot reveals that AsA, as silver granules, was distributed ubiquitously (Fig. 2A). The intensity of the silver granules in the flavedo tissues of shaded fruits became less intense toward the albedo (Figs. 2B, 2C, 2D). There was little silver granules in flavedo tissues adjacent to the albedo of fruits grown under $5 \%$ full sunlight; some silver granules appear to be localized in the cells adjacent to the epidermis (Fig. 2D).

\section{Discussion}

It is well known that AsA is synthesized from the precursor of hexose sugar in plants (Isherwood and Mapson, 1962; Loewus, 1971; Mapson, 1971) and that the chloroplasts contain about $30 \sim 40 \%$ of the total AsA within leafy vegetable cells (Foyer 

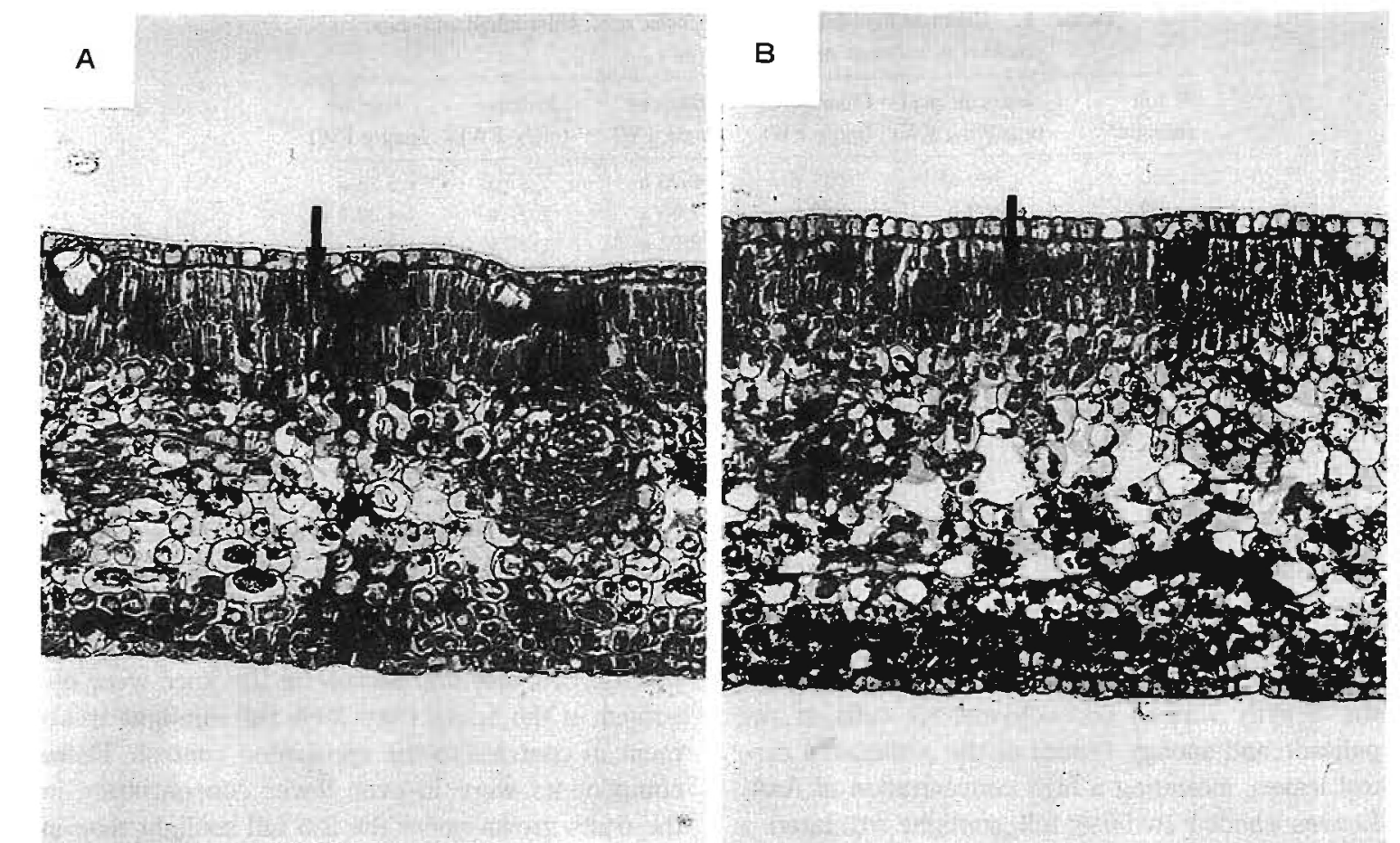

\section{c}
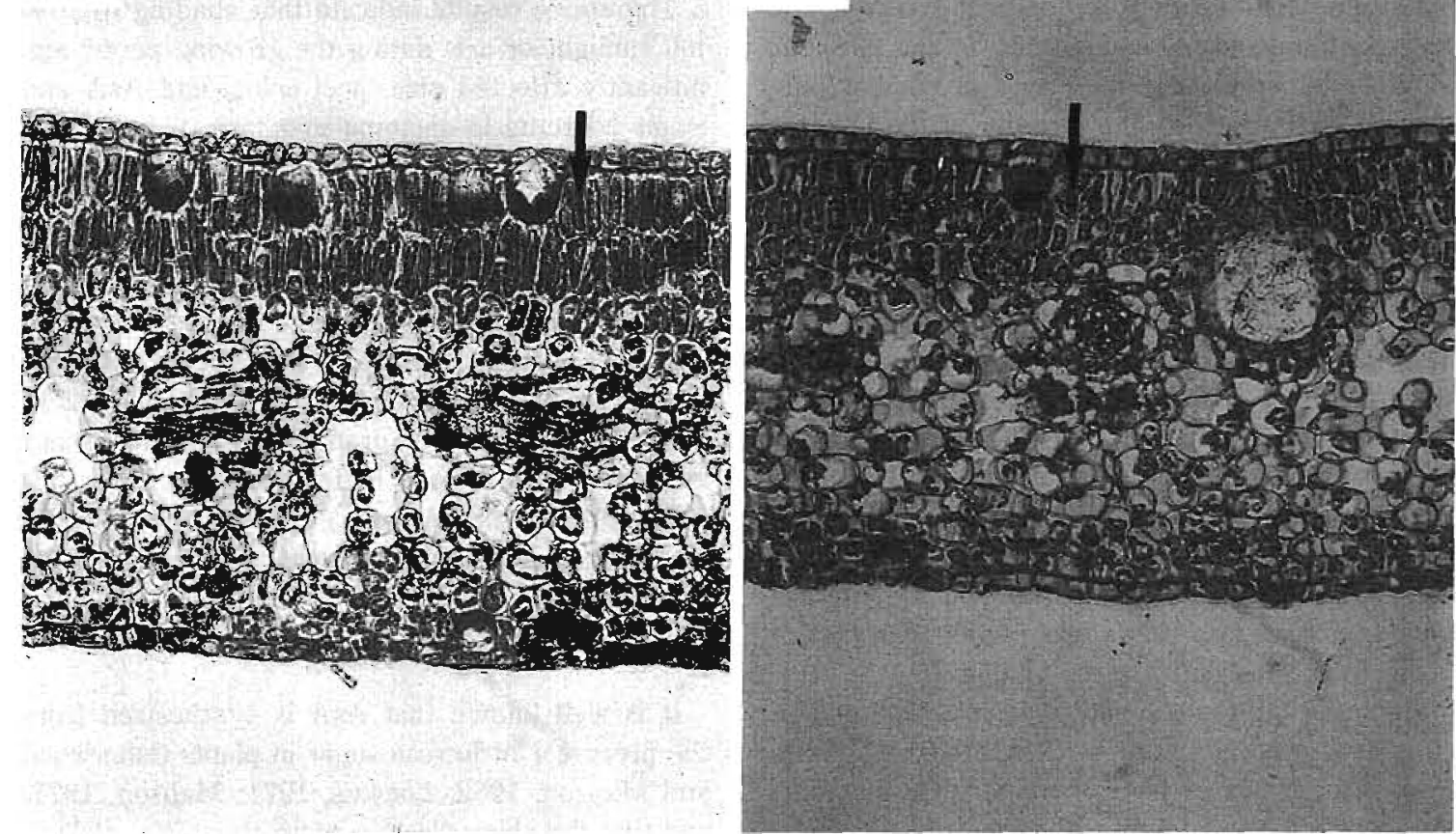

Fig. 1. Distribution of black silver deposits (arrows) after its reaction with ascorbic acid (AsA) in satsuma mandarin leaves (cross section). (A) $100 \%$ full sunlight, (B) $50 \%$ full sunlight, (C) $20 \%$ full sunlight and (D) $5 \%$ full sunlight. $(\times 100)$. 
Table 2. Effect of light intensity on fruit size and peel color of satsuma mandarin fruits.

\begin{tabular}{ccccc}
\hline \hline $\begin{array}{l}\text { \% full } \\
\text { sunlight }\end{array}$ & \multicolumn{2}{c}{ Fruit diameter $(\mathrm{cm})$} & & Fruit wt \\
& $\begin{array}{c}\text { Transverse } \\
\text { diameter }\end{array}$ & $\begin{array}{c}\text { Longitudinal } \\
\text { diameter }\end{array}$ & $\begin{array}{c}\text { Peel colour } \\
\text { a/b value }\end{array}$ \\
\hline 100 & $5.8 \mathrm{a}^{\mathrm{y}}$ & $4.8 \mathrm{a}$ & $81.8 \mathrm{a}$ & $0.33 \mathrm{~b}$ \\
50 & $5.5 \mathrm{~b}$ & $4.4 \mathrm{a}$ & $73.5 \mathrm{~b}$ & $0.39 \mathrm{a}$ \\
20 & $4.7 \mathrm{c}$ & $3.9 \mathrm{~b}$ & $48.5 \mathrm{c}$ & $0.02 \mathrm{c}$ \\
5 & $4.6 \mathrm{c}$ & $3.9 \mathrm{~b}$ & $46.2 \mathrm{c}$ & $-0.49 \mathrm{~d}$ \\
\hline
\end{tabular}

2. Treated from 19 Jul. to 19 Oct. 1989.

Y Different letters within a column represent significant differences according to Duncan's multiple range test $(p<0.05)$.

Table 3. Effect of light intensity on ascorbic acid and sugar contents in the flavedo of satsuma mandarin fruits.

\begin{tabular}{ccccc}
\hline $\begin{array}{c}\% \text { full } \\
\text { sunlight }^{2}\end{array}$ & $\begin{array}{c}\text { Ascorbic acid } \\
(\mathrm{mg} / 100 \mathrm{~g} \mathrm{FW})\end{array}$ & $\begin{array}{c}\text { Glucose } \\
(\mathrm{g} / 100 \mathrm{~g} \mathrm{FW})\end{array}$ & $\begin{array}{c}\text { Fructose } \\
(\mathrm{g} / 100 \mathrm{~g} \mathrm{FW})\end{array}$ & $\begin{array}{c}\text { Sucrose } \\
(\mathrm{g} / 100 \mathrm{~g} \mathrm{FW})\end{array}$ \\
\hline 100 & $193 \mathrm{a}^{\mathrm{y}}$ & $2.95 \mathrm{a}$ & $2.65 \mathrm{a}$ & $1.18 \mathrm{a}$ \\
50 & $196 \mathrm{a}$ & $2.73 \mathrm{~b}$ & $2.61 \mathrm{a}$ & $1.12 \mathrm{a}$ \\
20 & $108 \mathrm{~b}$ & $1.83 \mathrm{c}$ & $1.81 \mathrm{~b}$ & $1.01 \mathrm{a}$ \\
5 & $32 \mathrm{c}$ & $0.95 \mathrm{~d}$ & $1.00 \mathrm{c}$ & $0.67 \mathrm{~b}$ \\
\hline
\end{tabular}

2 Treated from 19 Jul. to 19 Oct. 1989.

y Different letters within a column represent significant differences according to Duncan's multiple range test $(p<0.05)$.

Table 4. Effect of light intensity on ascorbic acid, sugar and titratable acid (as citric acid) contents in the juice of satsuma mandarin fruits.

\begin{tabular}{cccccc}
\hline $\begin{array}{l}\text { \% full } \\
\text { sunlight }{ }^{2}\end{array}$ & $\begin{array}{c}\text { Ascorbic acid } \\
(\mathrm{mg} / 100 \mathrm{ml})\end{array}$ & $\begin{array}{c}\text { Glucose } \\
(\mathrm{g} / 100 \mathrm{ml})\end{array}$ & $\begin{array}{c}\text { Fructose } \\
(\mathrm{g} / 100 \mathrm{ml})\end{array}$ & $\begin{array}{c}\text { Sucrose } \\
(\mathrm{g} / 100 \mathrm{ml})\end{array}$ & $\begin{array}{c}\text { Titratable acid } \\
(\mathrm{g} / 100 \mathrm{ml})\end{array}$ \\
\hline 100 & $31.3 \mathrm{a}^{\mathrm{y}}$ & $2.07 \mathrm{a}$ & $2.27 \mathrm{a}$ & $3.71 \mathrm{a}$ & $1.08 \mathrm{~d}$ \\
50 & $31.1 \mathrm{a}$ & $2.24 \mathrm{a}$ & $2.38 \mathrm{a}$ & $3.59 \mathrm{a}$ & $1.26 \mathrm{c}$ \\
20 & $25.0 \mathrm{~b}$ & $1.65 \mathrm{~b}$ & $1.81 \mathrm{~b}$ & $3.00 \mathrm{~b}$ & $1.44 \mathrm{~b}$ \\
5 & $17.6 \mathrm{c}$ & $1.00 \mathrm{c}$ & $1.20 \mathrm{c}$ & $2.48 \mathrm{c}$ & $1.57 \mathrm{a}$ \\
\hline
\end{tabular}

$z$ Treated from 19 Jul. to 19 Oct. 1989.

y Different letters within a column represent significant differences according to Duncan's multiple range test $(p<0.05)$.

et al., 1983; Gerhardt, 1964). Therefore, light intensity which is closely associated with formation of chlorophyll and photosynthetic activity greatly influences the concentration of AsA in fruits and vegetables.

Our data indicate that AsA content in the leaves, especially in mesophyll tissues, diminished with decreasing light intensity. This trend of AsA content paralleled the sucrose content in the leaves, confirming a previous observation that a close relation exists between sucrose and AsA contents in citrus leaves (Izumi et al., 1990b).

The shaded leaves contained a higher chlorophyll content than did nonshaded control leaves. This is in agreement with a previous report that chlorophyll levels were consistently higher in shade leaves than in sun leaves of satsuma mandarin over the season (Izumi et al., 1990b). It is difficult 

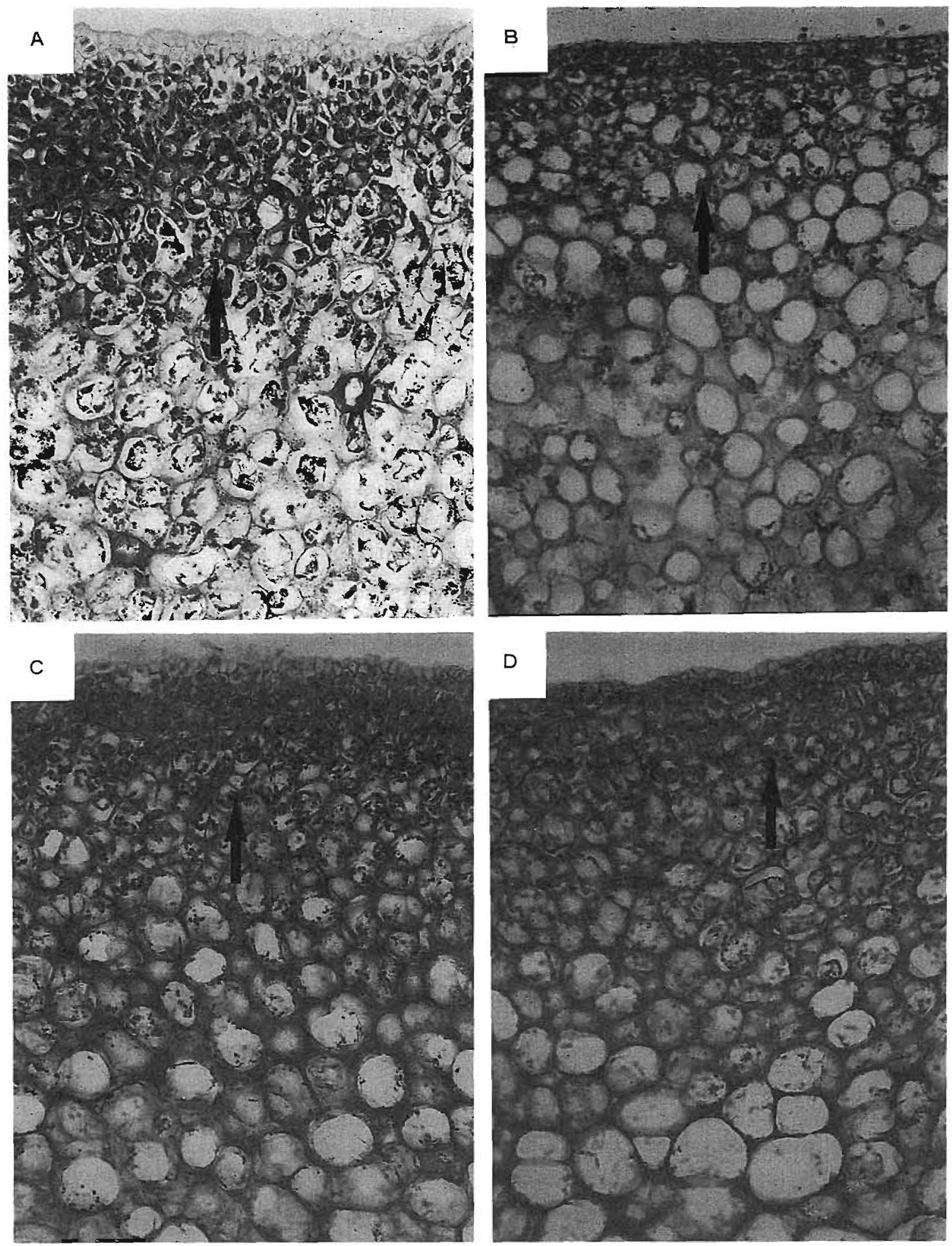

Fig. 2 Distribution of black silver deposits (arrows) after its reaction with AsA in flavedo of satsuma mandarin fruits (cross section). (A) $100 \%$ full sunlight, (B) $50 \%$ full sunlight, (C) $20 \%$ full sunlight and (D) $5 \%$ full sunlight. $(\times 100)$. 
from this study to clarify the relationship between leaf chlorophyll and AsA contents. However, since there are reports which indicate shade-grown leaves had lower net photosynthetic rates at saturated light intensity in spite of a higher chlorophyll content compared to sun-grown leaves (Amano et al., 1972; Syvertsen, 1984; Syvertsen and Smith, 1984), it may be inferred that AsA production in satsuma mandarin leaves was affected by the amount of photosynthates rather than by its chlorophyll content.

Manipulating light intensity revealed that shade fruits from the trees grown under $50 \%, 20 \%$, and $5 \%$ levels of full sunlight were smaller, and that the fruits from the $20 \%$ and $5 \%$ full sunlight treatments had inferior peel color compared with exposed fruits. These results are consistent with other reports (Kuriyama and Shiraishi, 1970; Nii and Deguchi, 1972; Ono and Iwagaki, 1987; Suzuki et al., 1988). Glucose, fructose and sucrose contents in the flavedo and juice were also affected by light intensity. These carbohydrate contents were lower in the fruits from $20 \%$ and $5 \%$ levels of full sunlight than were the control, except sucrose content in the flavedo. Kuriyama and Shiraishi (1970) reported that shading to $50 \%$ light level reduced total sugar content in the juice of satsuma mandarin fruits. We found, moreover, that reducing light intensity to $20 \%$ full sunlight decreased the concentration of the three predominant sugars in the juice and flavedo. On the other hand, there have been two different observations with respect to the effect of shading on acid content in the juice of satsuma mandarin fruits. Some authors (Nii and Deguchi, 1972; Suzuki et al., 1988) have reported that the juice of shaded fruits contained a higher acid content than had the juice of exposed fruits; others (Ashizawa et al., 1969; Kuriyama and Shiraishi, 1970) reported no significant differences in acid content in the juices of shaded and exposed fruits. The result in this study was similar to the former. Other reports indicated that the changes in acid content in the juice were affected by temperature during fruit growth of satsuma mandarin (Nii et al., 1970; Sakamoto and Okuchi, 1968), Valencia orange (Cooper et al., 1963), and grapefruit (Young et al., 1969). We consider that acid content of citrus fruits seems to be affected by not only light intensity but also by the temperature during the growing period.
AsA content in the flavedo and juice, as well as sugar content, was lower in the fruits grown in $20 \%$ full sunlight than in the unshaded ones, whereas fruits from the $5 \%$ full sunlight treatment contained even less AsA in the flavedo and juice than did the fruits from the $20 \%$ full sunlight treatment. Suzuki et al. (1988) reported that when satsuma mandarin trees were grown in 5 different light conditions ( $100,70,50,25$ and $10 \%$ levels of full sunlight) during all seasons, AsA content in the juice was lower in the fruits grown in $25 \%$ and $10 \%$ levels of full sunlight than in those grown in full sunlight. It is evident from this study that the effect of light intensity on AsA content is greater in the flavedo exposed to direct sunlight during development than that in the juice. Furthermore, the histological observation revealed that there is much more AsA in the exposed flavedo cells than there is in cells from the shaded side of the fruit.

From the localization of AsA in the leaves and fruits, we conclude that light intensity affects its amount and distribution in the major source and sink for photosynthates. Our data also indicate that fruits grown under $20 \%$ and $5 \%$ full sunlight are inferior in fruit quality, especially with respect to AsA content in the juice and flavedo compared to fully exposed fruits. The previous report indicated that light intensity in the dark interior of the canopy of satsuma mandarin tree ranged from 5 to $10 \%$ of that of the canopy periphery (Izumi et al., $1990 \mathrm{~b})$. Therefore, it is the difference in light intensity between the exterior and interior portions of the foliar canopy during fruit development which contributes to the variation in fruit quality within the crop on the same trees as we postulated earlier (Izumi et al., 1988, 1990a).

\section{Acknowledgement}

The authors thank Dr. Takao Murata, Professor of Shizuoka University, for his critical reading of the manuscript.

\section{Literature Cited}

Amano, S., A. Hino, H. Daito and T. Kuraoka. 1972. Studies on photosynthetic activity in several kinds of fruit trees. I. Effect of some environmental factors on the rate of photosynthesis. J. Japan. Soc. Hort. Sci. 41 : 144-150. (In Japanese with English summary).

Ashizawa, M., T. Chujo, S. Fujiwara and T. Miyatake. 
1969. Role of leaves on the fruit growth and quality in the later stage of development. Part II. Satsuma mandarin. Abstr. Japan. Soc. Hort. Sci. Spring Meet. : 40-41. (In Japanese).

Cooper, W.C., A. Peynado, J.R. Furr, R. H. Hilgeman, G.A. Cahoon and S.B. Boswell. 1963. Tree growth and fruit quality of Valencia oranges in relation to climate. Proc. Amer. Soc. Hort. Sci. $82: 180-192$.

Foyer, C., J. Rowell and D. Walker. 1983. Measurement of the ascorbate content of spinach leaf protoplasts and chloroplasts during illumination. Planta $157: 239-244$

Gerhardt, B. 1964. Untersuchungen über Beziehungen 2wischen Ascorbinsäure und Photosynthese. Planta $61: 101-129$.

Isherwood, F. and L. W. Mapson. 1962. Ascorbic acid metabolism in plants. Part II. Biosynthesis. Ann. Rev. Plant Physiol. 13 : 329-350.

Izumi, H., T. Ito and Y. Yoshida. 1988. Relationship between ascorbic acid and sugar content in citrus fruit peel during growth and development. J. Japan. Soc. Hort. Sci. 57:304-311. (In Japanese with English summary).

Izumi, H., T. Ito and Y. Yoshida. 1990a. Sugar and ascorbic acid contents of satsuma mandarin fruits harvested from exterior and interior canopy of trees during fruit development. J. Japan. Soc. Hort. Sci. 58 : 877-883. (In Japanese with English summary).

Izumi, H., T. Ito and Y. Yoshida. 1990b. Seasonal changes in ascorbic acid, sugar and chlorophyll contents in sun and shade leaves of satsuma mandarin and their interrelationships. J. Japan. Soc. Hort. Sci. 59: 389-397. (In Japanese with English summary).

Kuriyama, T. and S. Shiraishi. 1970. Studies on fruit quality of satsuma mandarin. Part VIII. Fruit quality in relation to the light intensity and time for shading. Abstr. Japan. Soc. Hort. Sci. Autumn Meet. : 14-15. (In Japanese).

Kurosaki, T. and I. Kawakami. 1974. Histochemical and biochemical studies on satsuma mandarins. I. Seasonal fluctuations in the distribution and concentration of ascorbic acid within pulp and peel tissues during growth of satsuma mandarin fruit. J. Japan. Soc. Hort. Sci. $43: 189-193$. (In Japanese with
English summary).

Loewus, F. 1971. Carbohydrate interconversions. Ann. Rev. Plant Physiol. 22 : 337-364.

Mapson, L.W. 1971. Vitamins in fruits. p. 369-384. In : A. C. Hulme (ed.). The biochemistry of fruits and their products. Vol. 1. Academic Press.

Nii, N., K. Harada and K. Kadowaki. 1970. Effects of temperature on the fruit growth and quality of satsuma oranges. J. Japan. Soc. Hort. Sci. 39 : 309-317. (In Japanese with English summary).

Nii, N. and N. Deguchi. 1972. Effect of light conditions on the development of satsuma mandarin fruits. Agriculture and Horticulture 47:81-82. (In Japanese).

Ono, S. and I. Iwagaki. 1987. Effects of shade treatment on the productive structure of satsuma mandarin trees. Bull. Fruit Tree Res. Stn. D 9 :13-24. (In Japanese with English summary).

Sakamoto, T. and S. Okuchi. 1968. Effects of temperature on acid and soluble soliỏs in satsuma oranges. J. Japan. Soc. Hort. Sci. 37 : 115-121. (In Japanese with English summary).

Sinclair, W.B. 1984. The biochemistry and physiology of the lemon and other citrus fruits. p. 16-183. Div. Agr. Nat. Res., Univ. of California.

Sosa, J.M. 1952. Vitamin C microscopic demonstration and Golgi apparatus. Exptl. Cell Res. 3 : 184-191.

Suzuki, T., T. Takagi, I. Masuda and S. Okamoto. 1988. Effect of relative light intensity on the growth, photosynthesis and fruit quality of satsuma mandarin trees. Part I. Effect of shading during whole seasons on tree growth and fruit quality. Agriculture and Horticulture 63:1103-1104. (In Japanese).

Syvertsen, J.P. 1984. Light acclimation in citrus leaves. II. $\mathrm{CO}_{2}$ assimilation and light, water, and nitrogen use efficiency. J. Amer. Soc. Hort. Sci. $109: 812-817$.

Syvertsen, J.P. and M. L. Smith, Jr. 1984. Light acclimation in citrus leaves. I. Changes in physical characteristics, chlorophyll, and nitrogen content. J. Amer. Soc. Hort. Sci. 109 : 807-812.

Young, R., F. Meredith and A. Purcell. 1969. Redblush grapefruit quality as affected by controlled artificial climates. J. Amer. Soc. Hort. Sci. 94 : 672-674. 
栽培中の光条件がウンシュウミカンの葉と果皮中のアスコルビン酸含量と

分布および果実品質に及ぼす影響

泉 秀実・伊東卓爾・吉田保治

近畿大学附属農場 643 和歌山県有田郡晹浅町

\section{摘要}

ウンシュウミカン“宮本早生’の幼樹を 7 月から 10 月 にかけて 4 段階の照度(自然光の $100 ， 50 ， 20 ， 5 \%$ ) のもとで栽培した。

10 月の春葉のアスコルビン酸含量とショ糖含量は, 自然光下に比べて受光量が少ないほど低くなったが, クロロフィル含量は遮光区の方が高い值を示した．ア スコルビン酸は葉肉部の柔細胞中に分布し, 受光量が 少ない葉はど葉肉部全体にわたって密度が低くなるこ とが観察された。

収穫時の果実品質を比較すると, 自然光の $20 \% の$ 照 度では果実の大き，果皮色，フラべドおよび果汁中 のアスコルビン酸および糖含量の低下がみられ，5\%
区ではこれらの各成分含量はさらに低い值を示した。 果汁中の酸含量は逆に遮光区で高い值を示した。

フラベド中のアスコルビン酸の分布を顕微鏡下で観 察すると, 受光量の多い果実ではフラべド部全体の細 胞にアスコルビン酸が観察されたが，20\%および5\% 照度の遮光区ではアルベド部に近づくに従って顕著に 少なくなった。

以上の結果から，受光量はウンシュウミカンの果実 および葉のアスコルビン酸の含量と組織内の分布に大 きな影響を与之, 自然光の $20 \%$ 以下の受光量では明ら かに果実品質の低下することが認められた。 